\title{
Socially responsible development strategies of the leading regional enterprises
}

\author{
Tetyana Batrakova \\ Zaporizhya National University \\ Zhukovskogo str. 66, 69600, Zaporizhya \\ Ukraine \\ e-mail: t.i.batrakova@mail.ru \\ Oleg Gelikh \\ Herzen State Pedagogical University of Russia \\ 48 Moyka Emb., 191186, Saint Petersburg \\ Russian Federation \\ e-mail: ogelich@yandex.ru \\ Alla Shapovalova \\ Department of Philosophy and Political Science \\ Interregional Academy of Personnel Management \\ Frometivska str. 2, 02000, Kyiv \\ Ukraine \\ e-mail: $\underline{\text { a_shan65@ukr.net }}$
}

\begin{abstract}
This paper tackles the need for the elaboration of the theoretical basis and the development of practical recommendations for integrating the principles of a socially responsible concept into the strategic development of domestic enterprises. Achieving this task appears to be important in order to consolidate private and public priorities of increasing the competitiveness of Ukrainian business.

Our paper is based on an own and original survey. The basis for the survey became the information obtained through the survey of 500 respondents of small, medium and large enterprises of the Odessa region by the method of personal interviews, talks and questionnaires in 2016. The obtained results of the study were analyzed on the basis of a systematic approach using the method of structuring, empirical research and statistical analysis, expert evaluations and comparison, generalization, analysis and synthesis.

Our results demonstrate that a socially responsible strategy of the development of enterprises of the region of any production size should consider the harmonization of the socially-economic interests of the concerned parties in order to prevent the emergence of economic conflicts.
\end{abstract}

\section{Introduction}

The development of Ukrainian enterprises as well as the country's involvement in globalization processes and economic integration outlines new priorities for the Ukrainian business that are associated with the activation of processes in the area of social responsibility. Business can not be developed independently from society, developed since it is itself an element of the public, whose activity depends on the quality and safety of consumer goods, the state of the environment, and so on. Therefore, the social orientation of the Ukrainian enterprises will become more productive if the socially responsible concept is integrated into the strategy of their development. In the western countries, the evolution of the socially responsible concept is characterized by longterm development, when its theoretical aspects have been widely implemented in the practice of foreign business. However, the recognition of the correlation between socially responsible behavior and a strategic development of enterprises in the theoretical platform has recently received great interest among the authors whose views are rather ambiguous and controversial (for example, Dhaliwal et al. 2011; Janda et al. 2013; Barone et al. 2013; Moskalenko and Yevsieieva 2015; or Narkuniené and Ulbinaite, 2018).). Such a controversy of views is provoked by the fact that the dominant trend in the research of many scholars is the discussion of the positive dependence between the socially responsible concept and the strategic development of enterprises (Amaladoss and Manohar 2013; Hsu and Cheng 2012; Chládková 2015; Čábelková et al. 2015; Reiff et al. 2016; Gryshova et al. 2017a; 2017b; Ushakov et al. 2017; Batkovskiy et al. 2018; or Białowąs 2018), while the rest of the academic circle emphasize the negative dependence between these phenomena or the lack of correlation between them in general (for example, Malcolm et al. 2012; Laforet 2013; or Zemguliene and Valukonis 2018). 
Thus, some representatives of the scientific community (De Geer 2005; Derwall et al. 2011) questioned the above-mentioned interdependence, noting that any results obtained by examining a direct correlation between the socially responsible concept and the strategic development of enterprises can not be $100 \%$ reliable because this interdependence can be influenced by a number of interventional dominant ones that are not accounted for in many studies. Therefore, the relationship between the socially responsible concept and the strategic development of enterprises is a rather difficult issue, which has been paid to little attention in previous studies.

The evolution of the concept of corporate social responsibility is characterized by more than six decades of scientific discussion in the direction of the disclosure of the economic nature of the definition "social responsibility", as a result of which this concept has gained an enormous spread both in the theoretical aspect of the management of the organization (Kraus et al. 2012; Yin 2010; Yin 2014; Reyes-Rodríguez et al. 2014) and in integrating the principles of corporate social responsibility into its strategic activities (Laforet 2013; Russo and Perrini 2010; Santos 2011). As a result, today many theories of corporate social responsibility exist, the most urgent of which are: the corporate social responsibility, stewardship management, sustainable development and corporate sustainability, triple reporting and corporate social reporting. The general features of these theories are the dynamism of development and interdependence due to temporal and spatial transformations, while the theoretical differences in the sense of social responsibility, carried out as acts of goodwill and public accountability at all levels of the relations of business and society, are revealed in: its directions of implementation, functional content, means of promotion, composition of stakeholders, expected prospects and regulations. Thus, today the common in the understanding of a socially responsible strategy is that it is a peculiar philosophy of carrying out any activity in which the responsibility for the consequences of its impact on the society and the environment becomes a priority in the strategic development of domestic enterprises.

At the same time, the review of existing theoretical and methodological sources indicates the widespread use of the principles of a socially responsible concept in the strategy of development of enterprises only at the level of American or European practices (Porter and Kramer 2011), while at the level of developing countries, in particular in the Ukrainian context, only a basis for integrating the principles of the concept of corporate social responsibility into the business sector is laid. Therefore, the main prospect of the current study is based on the analysis of the impact of the corporate social responsibility on the strategic development of enterprises in the region, since the competitiveness and image of Ukrainian business both in the domestic and foreign markets depends on the level of consolidation of private and public priorities of development. Accordingly, the hypothesis of the study is as follows:

- Firstly, understanding of the phenomenon of social responsibility among enterprises in the region depends on the level of its popularization;

- Secondly, the potential incentives for the enterprises of the region to implement socially responsible directions depend on the production sizes of enterprises;

- Thirdly, the leaders of the business sector of the Odessa region correlate the use of communicative tools with the public with active charitable activities. They develop strategic projects of economic development in the context of integrating certain social and environmental components;

- Fourthly, the socially responsible strategy of the development of enterprises of the region of any production sizes should take into account the harmonization of socially economic interests of the concerned parties in order to prevent the emergence of economic conflicts.

\section{Material and methods of research}

The basis for the survey was the information obtained through a survey of 500 respondents of small, medium and large enterprises of the Odessa region by the method of personal interviews, talks and questionnaires in 2016. The results of the research carried out by the Center of Development of Corporate Social Responsibility, in particular concerning the development of corporate social responsibility in the sphere of small and medium business, are also used, but at the same time it is characterized by a deeper understanding of social responsibility, based on the new international standard-guidance on social responsibility of ISO 26000. Together with this, their imprint in respondents' answers was also found in actual events that are taking place today in Ukraine, including: the development of the national CSR Strategy, National Standard for Social Responsibility, etc.

The research has been carried out on the basis of a systematic analysis of the influence of the socially responsible concept on the strategic development of enterprises in the region. The following methods were used to solve the problems: structuring - in studying the level of popularization of the socially responsible concept among enterprises of the region; empirical research and statistical analysis - in analyzing the potential incentives of enterprises in the region to realize social trends in terms of their production sizes; expert assessments and comparisons - in the analysis of measures of socially responsible concept, which are realized by the enterprises 
of the region as acts of goodwill and observance of legal norms; generalization analysis and synthesis - when it is proved that the development of a socially responsible strategy of the development of enterprises of the region of any production sizes should take into account the harmonization of the socio-economic interests of the parties concerned in order to prevent the emergence of economic conflicts.

\section{Results and discussions}

According to the results of a survey of 500 respondents from enterprises of the Odessa region by the method of personal talks, interviews and questionnaires, it has been established that until recently, the enterprises in the region had little experience in implementing the principles of social responsibility in their strategic development. However, since 2005, the level of popularization of the socially responsible concept among the enterprises of the Odessa region has been gradually increasing, which, according to many researchers, is primarily due to: the commercialization of media companies' relations with regard to the dissemination of information from Corporate Social Responsibility; the effect of the financial and economic crisis in the country; Subjective understanding by entrepreneurs of the feasibility of introducing the principles of social responsibility.

However, it should be noted that significant changes in the trends of understanding the socially responsible concept among the enterprises of the Odessa region have begun sinse 2010 and up to now, the dependence of the scale of popularization of which correlates with the production sizes of enterprises (Table 1).

Table 1. The level of popularization of socially responsible concept among enterprises of the Odesa region, in $\%$

\begin{tabular}{|l|c|c|c|c|}
\hline & Small & Medium & Large & Total \\
\hline $\begin{array}{l}\text { Have heard about the phenomenon of } \\
\text { social responsibility }\end{array}$ & 75,0 & 86,9 & 91,8 & 76,3 \\
\hline $\begin{array}{l}\text { Have not heard about the phenomenon } \\
\text { of social responsibility of business }\end{array}$ & 25,0 & 13,1 & 8,2 & 23,7 \\
\hline
\end{tabular}

Source: Own results

The conducted study clearly demonstrated that social responsibility was the most widespread among the large industrial enterprises of the Odessa region (91.8\%), while $25.0 \%$ of small business forms did not even hear about this phenomenon at all. In the circle of small and medium-sized enterprises in the region, the phenomenon of social responsibility is either not a very popular phenomenon or is regarded as an additional task rather than a strategic one. In big enterprises of the region, the implementation of the directions of corporate social responsibility is primarily put at designated departments (for example, the marketing department, PR), while solitary cases of socially responsible measures implemented by small and medium enterprises are considered as a part of the daily life of the enterprise and are not of a formal nature. Undoubtedly, this attitude gives rise to certain differences and in their implementation of various socially responsible measures in terms of their production sizes, which depends, first of all, on the potential incentives and expected benefits from the implementation of socially responsible activities (Table 2).

Table 2. Incentives for socially responsible measures by enterprises of the Odessa region, in \%

\begin{tabular}{|l|c|c|c|}
\hline \multicolumn{1}{|c|}{ Stimulus } & Small & Medium & Big \\
\hline Obtaining of state financial support & 80,2 & 73,5 & 48,5 \\
\hline Reduction of tax pressure & 63,9 & 56,7 & 72,5 \\
\hline Compatible social projects & 31,6 & 25,6 & 27,0 \\
\hline $\begin{array}{l}\text { Distribution of the database of social and information } \\
\text { programs }\end{array}$ & 14,9 & 17,9 & 18,1 \\
\hline $\begin{array}{l}\text { Positive examples of implementation of social } \\
\text { responsibility }\end{array}$ & 1,6 & 6,2 & 6,6 \\
\hline
\end{tabular}

Source: Own results

The conducted research has proven that for small and medium enterprises of the Odessa region the priority incentive for realization of socially responsible directions is obtaining state financial aid, while for big enterprises of the region this incentive is inferior to preferential taxation. The priorities for the majority of regional enterprises are social projects compatible with local authorities, other enterprises, as well as the distribution of social and information programs. Such attitude of representatives of big enterprises of the Odessa region to socially responsible measures indicates their readiness for the implementation of social projects, as most of them understand and accept social responsibility as an instrument for the formation of competitive advantages and ensuring stable competitive positions in the markets both inside the country and 
beyond its boundaries.

In today's realities, business leaders in the region are correlating with the use of communicative tools with the public with active charitable activities, developing strategic projects of economic development in the context of integrating certain social and environmental components, while the rest of the big enterprises of the region have not yet identified with a socially responsible strategy of development, being in the point of crossing the observance of legal norms and the implementation of individual acts of goodwill (Table 3).

Table 3. Components of the socially responsible strategy of big enterprises of the Odessa region (2016)

\begin{tabular}{|l|c|}
\hline \multicolumn{1}{|c|}{ Directions of realization } & $\%$ \\
\hline Organization of work and production process & 67,3 \\
\hline Development of human resources and labor relations & 62,5 \\
\hline Charity & 55,1 \\
\hline Ethical and responsible attitude towards consumers & 49,5 \\
\hline Participation in regional development programs & 32,3 \\
\hline Environmental protection measures & 19,7 \\
\hline Relations with the authorities & 10,8 \\
\hline Open submission of information on the activity & 8,2 \\
\hline
\end{tabular}

Source: Own results

Thus, over $67.3 \%$ of the leaders of enterprises in the Odessa region prefer the organization of labor and production process, which involves compliance with environmental and safe standards of the production process; $62.5 \%$ direct investments in human resources development and labor relations improvement, which includes protection and hygiene of the work, improvement of the personnel qualification level and provision of their adequate social protection; $55.1 \%$ provide charitable assistance to the local community; $47.3 \%$ have ethical attitude towards customers being responsible for the safety of sales technology, providing accurate and true information in product advertising for the establishment of good relations with customers. In the context of practical implementation, the most unacceptable for the leaders of entrepreneurship in the Odessa region remain:

- environmental protection measures $(19.7 \%)$, which include the implementation of their own environmental policy, public reporting on compliance with environmental norms;

- relations with the authorities $(10.8 \%)$, based on an open dialogue between the business and public sectors, transparency and openness of lobbying relations with the aim of improving the employment policy of the population, observance of environmental norms, etc.;

- Only $8.2 \%$ of business units provide open information about their business results.

In the same time, one can not but ignore the fact that the development of a socially responsible strategy of the development of enterprises in the Odessa region of any production sizes should take into account the socio-economic interests of other parties in order to prevent the emergence of economic conflicts. Therefore, for the purpose of conducting an assessment of the level of harmonization of interests of enterprises of the Odessa region with the socio-economic interests of interested parties, we have calculated an integral indicator of harmonization according to Table 4.

Table 4. Assessment of the level of harmonization of interests of enterprises of the Odessa region with the concerned parties (2016)

\begin{tabular}{|l|c|c|c|c|c|}
\hline & Least & Medium Limit $\begin{array}{l}\text { Number of } \\
\text { enterprises }\end{array}$ & $\%$ \\
\hline $\begin{array}{l}\text { The integral index of harmonization of interests with concerned } \\
\text { parties }\end{array}$ & 1,0 & 7,5 & 27,0 & 500 & 100,0 \\
\hline Social responsibility index for own staff & 1,0 & 4,3 & 11,0 & 971 & 97,1 \\
\hline Social Responsibility Index for the Regional Public & 1,0 & 2,0 & 8,0 & 676 & 67,6 \\
\hline Responsibility Index for business partners & 1,0 & 1,5 & 4,0 & 903 & 90,3 \\
\hline Customer Responsibility Index & 1,0 & 1,3 & 4,0 & 520,0 & 52,0 \\
\hline
\end{tabular}

Source: Own results

Our study showed that the value of the Integral Index of harmonization of interests with stakeholders 
fluctuates from 1.0 to $27.0 \%$, confirming that the desire of the representatives of enterprises of the Odessa region to coordinate their interests with the socio-economic interests of other concerned parties is rather low.

Out of 500 respondents interviewed in course of our research, $97.1 \%$, in the first place, favor the implementation of social responsibility measures for their own staff, which in fact is due to the shortage of skilled labor, first of all, in production. As a result, managers try to retain their own staff by providing them with additional benefits and opportunities to improve their qualifications. Today small enterprises in the region have insignificant opportunities to invest in communicative services with the local community or to integrate the principles of a socially responsible concept. However, all enterprises, despite their production size, play an important role in solving socio-economic problems of the development of the territories, because the shortage of skilled personnel is a problem for each of them. Also, the problem of thefts, which was partially acquired during the Soviet era and as a result of the low standard of living of the population, still remains. Therefore, many enterprises in the region believe that this, in its turn, leads to a significant decline in production productivity and inadequate gross output, which is reflected in the final results of business activity.

The second priority communicative measure is the socially responsible behavior of enterprises to the regional community, first of all, based on the use, of investment instruments. Thus, most enterprises in the Odessa region believe that there is a need not only for the support of their own employees, but also for the people who leases their land shares, is the main buyer of their products, etc.

One can not help avoiding the fact that for some enterprises of the region harmonization of interests with the regional community also has an ethical basis, caused by the limited possibilities of regional development on the part of the regional self-government. However, as practice shows, in any case, the driving force behind the harmonization of interests for enterprises is the formation of a positive image, and for the regional community it is a way of solving life problems, which, in its turn, requires effective communication support. However, most companies in the Odessa region, knowing the importance of such cooperation, do not imagine how to implement symmetrical bilateral long-term communications with the target audience. Other interested groups, such as business partners and customers, today are less important for enterprises in the region.

\section{Some implications}

The results obtained in the course of this research, yield some differences in the understanding of socially responsible behavior by the representatives of enterprises of the Odessa region, whose dependence of the scale of popularization correlates with their production sizes. These conclusions supplemented the view (Gryshov et al. 2017), and that the social responsibility phenomenon in the range of small and medium-sized enterprises of the Odessa region is not quite popular one or is considered as an additional rather than a strategic task of strategic development. Individual cases of implementation of socially responsible measures by small and medium enterprises of the region are considered as part of their everyday life and are not of formal nature.

The philosophy of development of big enterprises of the Odessa region testifies to their readiness for the implementation of social projects, since most of them understand and accept social responsibility as a tool for the formation of competitive advantages and ensuring stable competitive positions in the domestic and foreign markets first of all. The functions of implementing socially responsible measures are, put on assigned departments (for example, marketing department, PR).

The conducted research has shown incidental, fragmentary and informal interference by small enterprises of the region in the community and integration of the principles of a socially responsible concept into their strategic development. This fact is confirmed by Kraus et al. (2012), noting that many small and medium size enterprises are implementing some socially responsible trends without realizing that they are actually addressing corporate social responsibility issues. As a rule, the motive for realization of social directions is receiving the state financial aid. Such attitude to the implementation of socially responsible measures is also inherent in the activity of small British business, whose internal priorities are more powerful than external ones, and Porter and Kramer (2011), however, the majority of small Ukrainian businessmen, aware of the importance of cooperation with the public, do not imagine how to implement symmetrical bilateral long-term communications with the target audience.

The leaders of entrepreneurship in the Odessa region correlate the use of communicative tools with the public with active charitable activities, developing strategic projects of the economic development in the context of the integration of certain social and environmental components. The motive for realizing social projects is preferential taxation, ethical considerations, social projects compatible with local authorities and other enterprises, as well as distribution of the base of social and information programs. In any case, the driving force behind the harmonization of interests for enterprises in the Odessa region of any production sizes is to protect its business and create a positive image, and for the local community it is a way of solving life problems, which in its turn, requires effective communication support. . This is confirmed by Christensen's (2015) findings, who proves that the stimulus for the British business's economic development in the context of socially responsible behavior is to protect its core business, protect image and reputation of its brand (Myshchak et al. 2017). 
According to the results of the survey, large enterprises of the Odessa region use the principles of a socially responsible concept in the strategy of economic development for improving the level of competitiveness and image, rather than for saving profits from corporate social responsibility. A similar attitude is observed in the companies of Canada. The European Commission (European Commission 2012) believes that socially responsible behavior has a direct impact on the financial viability of the firm and the growth of its economic potential. However, unlike small firms, big companies use a more powerful potential for launching the mass media and implementing large-scale social projects, while the ability of small firms to use social communication is limited by their resource capabilities (De Gee 2005; Ireland et al. 2003). Despite the similar attitude to the importance and necessity of integrating the principles of a socially responsible concept into their activities, some representatives of big enterprises of the region have not yet been identified with a socially responsible development strategy, being at the point of crossing the observance of legal norms and the implementation of acts of goodwill solitary.

Many enterprises in the Odessa region do not possess of communicative tools, partly due to the lack of financial support (Gryshova et al. 2017a). Accordingly, the lack of financial resources and insufficient information and technical corporate social responsibility (Hsu and Cheng 2012) are the main obstacles to the official integration of the principles of socially responsible behavior into strategic development of the Ukrainian business units. The same is true of Amaladoss and Manohar (2013), arguing that small and medium-sized Ukrainian business units do not adequately understand the feasibility of introducing socially responsible measures.

\section{Conclusions}

The results stemming from our profound research of the socially responsible development strategies of the leading regional enterprises were tested in the direction of integrating the principles of a socially responsible concept into the strategic development of enterprises in the region and confirmed the hypotheses we have put forward. The potential incentives for the enterprises of the region for implementing socially responsible directions depend on the size of enterprises.

Overall, it turns out that the leaders of the business sector of the Odessa region are correlating with the use of communicative tools with the public with active charitable activities. They work out strategic economic development projects in the context of integrating certain social and environmental components. A socially responsible strategy of the development of enterprises of the region of any production sizes should take into account the harmonization of socio-economic interests of stakeholders in order to prevent the emergence of economic conflicts.

Our research showed that phenomenon of social responsibility has become the most widespread among the large enterprises of the Odessa region, while among the small and medium enterprises of the region it is not a popular phenomenon, or is considered as an additional, but not a strategic task of economic development. The solitary cases of implementation of socially responsible measures by the small and medium enterprises of the region are considered as a part of their everyday life and are not of a formal nature. They are characterized by occasional, fragmentary and informal interference with the public through the implementation of social measures for obtaining state financial assistance. The attitude of large enterprises of the Odessa region to socially responsible measures testifies to their readiness for realization of social projects. The majority of large enterprises of the region understands and accepts social responsibility as an instrument for forming competitive advantages, ensuring stable market positions and forming a positive image. The conducted study was verified in the direction of integrating the principles of a socially responsible concept into the strategic development of the enterprises of the Odessa region, which confirmed that the phenomenon of social responsibility among enterprises of the region depends on the level of their popularization. Potential incentives for the enterprises of the region to implement socially responsible directions depend on the production sizes of enterprises. The leaders of the business sector of the Odessa region correlate the use of communicative tools with the public with active charitable activities. They develop strategic economic development projects in the context of integrating certain social and environmental components.

\section{References}

Amaladoss M, Manohar H (2013) Communicating corporate social responsibility-a case of CSR communication in emerging economies. Corporate Social Responsibility and Environmental Management 20 (2):65-80. doi: $10.1002 /$ csr. 287 
Barone E, Ranamagar N, Solomon JF (2013) A Habermasian model of stakeholder (non) engagement and corporate (ir) responsibility reporting. Accounting Forum 37(3):163-181. doi: 10.1016/j.accfor.2012.12.001

Batkovskiy AM, Kalachikhin PA, Semenova EG, Telnov YF, Fomina AV, Balashov VM (2018) Configuration of enterprise networks. Enterpreneurship and Sustainability Issues 6(1):311-328. doi: 10.9770/jesi.2018.6.1(19)

Białowąs P (2018) Enterprise restructuring: a quality management paradigm. Czech Journal of Social Sciences, Business and Economics 7(1):24-28. doi: 10.24984/cjssbe.2018.7.1.3

Christensen DM (2015) Corporate accountability reporting and high-profi le misconduct. The Accounting Review 91(2):377-399. doi: 10.2308/accr-51200

Č́belková I, Abrhám J, Strielkowski W (2015) Factors influencing job satisfaction in post-transition economies: the case of the Czech Republic. International Journal of Occupational Safety and Ergonomics 21(4):448-456. doi: 10.1080/10803548.2015.1073007

De Geer H (2005) Foretagen i samhallet. In: Larsson O (ed.) Corporate Governance och hållbar affärsutveckling, Ekerlids Forlag: Stockholm, pp. 22-36.

Derwall J, Koedijk K, Ter Horst J (2011) A tale of values-driven and profit-seeking social investors. Journal of Banking \& Finance 35(8):2137-2147. doi: 10.1016/j.jbankfin.2011.01.009

Dhaliwal DS, Li OZ, Tsang A, Yang YG (2011) Voluntary nonfinancial disclosure and the cost of equity capital: The initiation of corporate social responsibility reporting. The Accounting Review 86(1):59-100. doi: 10.2308/accr.00000005.

European Commission (2012). EU SMEs in 2012: At the crossroads - Annual report on small and medium-sized enterprises in the EU. Enterprise Publications: Brussels. http://publications.europa.eu/resource/cellar/0bf8eb186ebf-4741-b434-b6c2db512a69.0001.01/DOC_1 Accessed 20 July 2018

Gryshova IYu, Zamlynskyi VA, Shestakovska TL (2017a) Implementing Cluster Forms into National Education Development Strategy. Science and education 5:56-61.

Gryshova IYu, Nikoliuk EV, Shestakovska TL (2017b) Conceptualization of the Organizational Management Mechanism of the Development of the National Education System in the Context of Its Quality. Science and education 10:118-125.

Hsu J, Cheng M (2012) What prompts small and medium enterprises to engage in corporate social responsibility? A study from Taiwan. Corporate Social Responsibility and Environmental Management 19(5):288-305. doi: 10.1002/csr.276

Ireland RD, Hitt MA, Sirmon DG (2003) A Model of Strategic Entrepreneurship: The Construct and Its Dimensions. Journal of Management 29(6):963-989. doi: 10.1016/s0149-2063_03_00086-2

Janda K, Rausser G, Strielkowski W (2013) Determinants of profitability of Polish rural micro-enterprises at the time of EU Accession. Eastern European Countryside 19:177-217. doi: 10.2478/eec-2013-0009

Kraus S, Rigtering JP, Hughes M, Hosman V (2012) Entrepreneurial orientation and the business performance of SMEs: a quantitative study from the Netherlands. Review of Managerial Science 6(2):161-182. doi: 10.1007/s11846-011-0062-9

Laforet S (2013) Organizational innovation outcomes in SMEs: Effects of age, size, and sector. Journal of World Business 48(4): 490-502. doi: 10.1016/j.jwb.2012.09.005

Moskalenko V, Yevsieieva I (2015) Effective leadership conflict management in food technology enterprises. International Economics Letters 4(2):91-102. doi: 10.24984/iel.2015.4.2.4

Myshchak IM, Konarivska OB, Seysebaieva NG (2017) Adjustment of the Inclusive Education Legal Insurance in Ukraine to International Norms and Standards. Science and Education 10:139-146.

Narkunienè J, Ulbinaite A (2018). Comparative analysis of company performance evaluation methods. Entrepreneurship and Sustainability Issues 6(1):125-138. doi:10.9770/jesi.2018.6.1(10)

Porter ME, Kramer M (2011) Creating Shared Value. Harvard Business Review 89(1/2):62-77.

Reiff M, Surmanová K, Balcerzak AP, Pietrzak MB (2016) Multiple criteria analysis of European Union agriculture. Journal of International Studies 9(3):62-74. doi:10.14254/2071-8330.2016/9-3/5 
Reyes-Rodríguez J, Ulhøi J, Madsen H (2014) Corporate environmental sustainability in Danish SMEs: A longitudinal study of motivators, initiatives, and strategic effects. Corporate Social Responsibility and Environmental Management 23(4):193-212. doi: 10.1002/csr.1359

Russo A, Perrini F (2010) Investigating stakeholder theory and social capital: CSR in large firms and SMEs. Journal of Business Ethics 91:207-221. doi: 10.1007/s10551-009-0079-Z

Santos M (2011) CSR in SMEs: strategies, practices, motivations and obstacles. Social Responsibility Journal 7(3):490-508. doi: 10.1108/17471111111154581

Ushakov D, Bandurin V, Bandurin A (2017) Taxation regime as a factor of mutually intergrated macroeconomic systems' dynamics. Montenegrin Journal of Economics 13(1):171-179. doi: 10.14254/1800-5845/2017.13-1.12

Yin RK (2014) Case Study Research: Design and Methods, 5th edn. (SAGE, Thousand Oaks: New York, 2014), $312 \mathrm{p}$.

Yin RK, Qualitative Research from Start to Finish, 2nd edn. (Guilford Publications: New York, 2010), 386 p.

Zemguliene J, Valukonis M (2018) Structured literature review on business process performance analysis and evaluation. Entrepreneurship and Sustainability Issues 6(1):226-252. doi: 10.9770/jesi.2018.6.1(15) 